\title{
Materials Processing In Magnetic Fields
}


This page intentionally left blank 


\title{
Materials Processing In Magnetic Fields
}

\author{
Proceedings of the International Workshop on Materials Analysis \\ and Processing in Magnetic Fields \\ Tallahassee, Florida $\quad 17-19$ March 2004
}

editors

\section{Hans J Schneider-Muntau}

Florida State University, USA

\section{Hitoshi Wada}

National Institute for Materials Science, Japan

\section{Noworld Scientific}




\section{Published by}

World Scientific Publishing Co. Pte. Ltd.

5 Toh Tuck Link, Singapore 596224

USA office: 27 Warren Street, Suite 401-402, Hackensack, NJ 07601

UK office: 57 Shelton Street, Covent Garden, London WC2H 9HE

\section{British Library Cataloguing-in-Publication Data}

A catalogue record for this book is available from the British Library.

\section{MATERIALS PROCESSING IN MAGNETIC FIELDS \\ Proceedings of the International Workshop \\ Copyright (C) 2005 by World Scientific Publishing Co. Pte. Ltd.}

All rights reserved. This book, or parts thereof, may not be reproduced in any form or by any means, electronic or mechanical, including photocopying, recording or any information storage and retrieval system now known or to be invented, without written permission from the Publisher.

For photocopying of material in this volume, please pay a copying fee through the Copyright Clearance Center, Inc., 222 Rosewood Drive, Danvers, MA 01923, USA. In this case permission to photocopy is not required from the publisher.

ISBN $981-256-372-5$

Printed in Singapore by Mainland Press 


\section{Editors' Preface}

Processing in magnetic fields is a rapidly expanding research area with a wide range of promising applications in materials science, development and design. Industry now offers a variety of superconducting magnets specifically designed for this purpose and equipped with cryocoolers that eliminate the need for cryogenic fluids. Numerous research centers dedicated to materials research and processing in magnetic fields have been created around the world. This book is the result of an international by-invitation-only workshop that has been organized to review the most recent activities in this field. Over 50 scientists participated and 39 papers were selected for inclusion in this book.

Magnetic fields are at the origin of many effects in materials, of which the following are a few examples. The high fields available now allow us to levitate diamagnetic matter with the advantage of containerless processing of materials, or control gravity on earth from several $-\mathrm{g}$ to $+\mathrm{g}$. The magnetization induced in dia- and paramagnetic matter is strong enough to change the structure and characteristics of materials, typically as a collective phenomenon. Magnetic anisotropy can be used for aligning fibers, polymers, and carbon nanotubes, resulting in matrix systems with superior quality. The magnetic field has an impact on texturing of materials during a phase transition, in both liquid-to-solid and solid-to-solid state transitions. Grain boundary migration and mobility changes have been demonstrated in $\mathrm{Bi}$ and $\mathrm{Zn}$ crystals, giving us a perspective for texture development in metals. The damping effect of magnetic fields on conductive liquids is exploited for improved crystal growth quality. Further research will investigate the use of static fields for convection and texture control, possibly at reduced gravity levels. Field geometry and the application of rotational fields are additional optimization parameters. Of growing interest are the effects of magnetic fields in biology and their beneficial applications. Magnetic fields can help manipulate cells and cellular processes, such as cell divisions. Magnetic microspheres can be guided within the body for drug delivery and tumor treatment. Another future application is to mix nanomagnetic particles with biological blood components for treatment, blood cell separation or as a marker. Other applications of magnetic field processing are magnetic separation, and processing of crystalline fibers through alignment. Additional research areas were presented and discussed during the workshop and are contained in this book.

The International Workshop on Materials Analysis and Processing in Magnetic Fields has been jointly organized and sponsored by the Tsukuba Magnet Laboratory of the National Institute for Materials Science in Tsukuba, Japan, and the National High Magnetic Field Laboratory of the Florida State University in Tallahassee, Florida. It was held at the NHMFL in Tallahassee on March 17-19, 2004. 
This page intentionally left blank 


\section{Table of Contents}

\section{EDITORS' PREFACE}

\section{Texturing and Phase Transitions}

APPLICATION OF HIGH MAGNETIC FIELDS IN MATERIALS PROCESSING

S. $A S A I$

HIGH MAGNETIC FIELDS EFFECTS ON SOLID STATE

TRANSFORMATIONS AT HIGH TEMPERATURE

E. BEAUGNON, F. GAUCHERAND

ENHANCEMENT OF MATERIAL PROPERTIES BY MAGNETIC

FIELD ASSISTED PHASE TRANSFORMATION

B.Z. CUI, K. HAN, H. GARMESTANI,

H.J. SCHNEIDER-MUNTAU, J.H. SU, J.P. LIU

EXPERIMENTAL INVESTIGATION OF THE CRYSTALLIZATION

OF BHF IN HIGH MAGNETIC FIELDS

W. ERTEL-INGRISCH, K. HARTMANN, X. WANG,

D. HÜLSENBERG

VARIATION OF PHASE TRANSFORMATION TEMPERATURE

IN FE-C ALLOYS IN A HIGH MAGNETIC FIELD

X.J. HAO, H. OHTSUKA, H. WADA

MARTENSITIC TRANSFORMATION IN SOME FERROUS

ALLOYS UNDER MAGNETIC FIELD

T. KAKESHITA

EXPLORING ULTRA-HIGH MAGNETIC FIELD PROCESSING

OF MATERIALS FOR DEVELOPING CUSTOMIZED

MICROSTRUCTURES AND ENHANCED PERFORMANCE

G.M. LUDTKA, R.A. JARAMILLO, R.A. KISNER, J.B. WILGEN,

G. MACKIEWICZ-LUDTKA, D.M. NICHOLSON,

T.R. WATKINS, P. KALU, R.D. ENGLAND 
FUNDAMENTALS AND APPLICATIONS OF GRAIN BOUNDARY

DYNAMICS IN HIGH MAGNETIC FIELDS

D.A. MOLODOV

ENHANCEMENT OF TEXTURE AND CRITICAL CURRENT

DENSITY IN $\mathrm{Bi}_{2} \mathrm{Sr}_{2} \mathrm{Ca}_{1} \mathrm{Cu}_{2} \mathrm{O}_{8}$ SUPERCONDUCTING TAPES

THROUGH MAGNETIC FIELD PROCESSING

P.V.P.S.S. SASTRY, U.P. TROCIEWITZ, H. MAEDA, J. SCHWARTZ

APPLICATION OF HIGH MAGNETIC FIELD TO TEXTURE MODIFICATION IN ZINC ALLOY

A.D. SHEIKH-ALI, D.A. MOLODOV, H. GARMESTANI

TEXTURING FROM LIQUID TO SOLID STATE BY ALIGNING

ANISOTROPIC MAGNETIC NUCLEI IN HIGH FIELDS

R.F. TOURNIER

\section{Chemical and Physical Processes}

REFRACTIVE INDICES OF WATER AND AQUEOUS ELECTROLYTE 115 SOLUTIONS UNDER HIGH MAGNETIC FIELDS

H. HOSODA, H. MORI, N. SOGOSHI, S. NAKABAYASHI

SYNTHESIS OF CARBON MATERIALS BY THE IMPOSITION

OF A HIGH MAGNETIC FIELD

M.-G. SUNG, K. SASSA, A. GEDANKEN, K. IWAI, S. ASAI

HIGHLY EXCITED MOLECULES IN MAGNETIC FIELDS

K. TAKAZAWA

APPLICATION OF HIGH MAGNETIC FIELD TO CHEMICAL AND PHYSICAL PROCESSES

Y. TANIMOTO, W. DUAN

MAGNETO-CHEMICAL SYSTEMS UNDER STRONG MAGNETIC FIELDS: FUNDAMENTALS AND APPLICATIONS

M. YAMAGUCHI, I. YAMAMOTO 


\section{Control of Liquids}

APPLICATIONS OF AC AND DC MAGNETIC FIELDS IN

METALLURGICAL AND CRYSTAL GROWTH PROCESSES

A. CRAMER, S. ECKERT, V. GALINDO, J. PRIEDE, G. GERBETH

ELECTROMAGNETIC PROCESSING OF MATERIALS: FROM

THE CONCEPTS TO INDUSTRIAL APPLICATIONS

Y. DELANNOY

SEMICONDUCTOR CRYSTAL GROWTH IN STATIC AND

ROTATING MAGNETIC FIELDS

M.P. VOLZ

\section{Magnetic Separation}

REMOVAL SYSTEM OF ARSENIC FROM GEOTHERMAL WATER BY MAGNETIC SEPARATION TECHNOLOGY WITH A SUPERCONDUCTING MAGNET

H. OKADA, K. MITSUHASHI, T. OHARA, H. WADA,

Y. KUDOH, H. NAKAZAWA, A. CHIBA

MAGNETICALLY ENHANCED SOLID-LIQUID SEPARATION

C.M. REY, K. KELLER, B. FUCHS

NEW APPLICATIONS OF MAGNETIC SEPARATION USING

SUPERCONDUCTING MAGNETS AND COLLOID CHEMICAL PROCESSES
S. TAKEDA, S.-J. YU, A. NAKAHIRA, Y. IZUMI,
S. NISHIJIMA, T. WATANABE

\section{Biological Applications}

NANOMAGNETICS IN BIOTECHNOLOGY

C.-J. CHEN, Y. HAIK, J. CHATTERJEE 
STRONG MAGNETIC FIELD INDUCED CHANGES OF GENE EXPRESSION IN ARABIDOPSIS

A.-L. PAUL, R.J. FERL, B. KLINGENBERG, J.S. BROOKS, A.N. MORGAN, J. YOWTAK, M.W. MEISEL

NEW APPLICATIONS OF MAGNETIC FIELD TO HUMAN

FRIENDLY MATERIALS AND HUMAN SUPPORTIVE SYSTEMS

S. TAKEDA, U. HAFELI, M. TONOIKE, Y. IZUMI, K. EMA,

S. NISHIJIMA

MAGNETIC ORIENTATION IN BIOLOGY: VIRUS STRUCTURE

- BLOOD CLOT ASSEMBLY - CELL GUIDANCE

J. TORBET

MANIPULATING CELLS WITH STATIC MAGNETIC FIELDS

J.M. VALLES, JR., K. GUEVORKIAN

\section{Diamagnetic Effects}

EFFECTS OF MAGNETIC FIELDS ON FEEBLE MAGNETIC MATERIALS

N. HIROTA, H. UETAKE, T. TAKAYAMA, H. NAKAMURA, M. KURASHIGE, S. HARA, Y. SAITO, Y. IKEZOE, T. ANDO, H. WADA, K. KITAZAWA

APPLICATION OF MAGNETIC LEVITATION TO PROCESSING OF DIAMAGNETIC MATERIALS

I. MOGI, K. TAKAHASHI, S. AWAJI, K. WATANABE, M. MOTOKAWA

PROTEIN CRYSTAL GROWTH IN LOW GRAVITY PROVIDED BY A NEW TYPE OF SUPERCONDUCTING MAGNET

N.I. WAKAYAMA, D.C. YIN, Y. TANIMOTO, M. FUJIWARA, K. HARATA, H. WADA 


\section{Magnetic Anisotropy and Alignment}

ALIGNMENT OF SINGLE WALL CARBON NANOTUBES UNDER 295 HIGH MAGNETIC FIELDS UTILIZING A SELFñORGANIZING OF EPOXY MATRIX

M.S. AL-HAIK, H. GARMESTANI, D.S. LI, M.Y. HUSSAINI, K. DAHMEN, R. TANNENBAUM

ENHANCEMENT OF NANO-MECHANICAL PROPERTIES OF AN 303 EPOXY PROCESSED UNDER HIGH MAGNETIC FIELDS M.S. AL-HAIK, H. GARMESTANI, D. LI, M.Y. HUSSAINI, R. TANNENBAUM, K. DAHMEN

PROCESSING OF POLYMERS USING MAGNETIC FIELDS E.P. DOUGLAS

PROCESSING OF POLYMERIC MATERIALS UNDER MAGNETIC FIELDS

T. KIMURA, M. YAMATO

MAGNETIC FIELD CONTROL OF STRUCTURES AND PROPERTIES 330 OF DIAMAGNETIC MOLECULAR ASSEMBLIES

I. OTSUKA, T. TAKAHASHI, Y. YAGUCHI, H. ABE, S. OZEKI

MAGNETIC ALIGNMENT AND CRYSTALLIZATION BEHAVIOR OF ISOTACTIC POLYSTYRENE

M. YAMATO, T. KIMURA

\section{Other Topics}

INDUSTRIAL APPLICATIONS OF MAGNETIC RESONANCE M.J. HENNESSY

GENERATION OF UNIFORM MAGNETIC FORCE FIELDS

O. OZAKI, S. MATSUMOTO, T. KIYOSHI, H. WADA 
xii

EFFECT OF MAGNETIC FIELDS ON EXPLOSIVE WELDING OF METALS AND EXPLOSIVE COMPACTION OF POWDERS G.A. SHVETSOV, V.I. MALI, YU.L. BASHKATOV, A.G. ANISIMOV, A.D. MATROSOV, T.S. TESLENKO

AUTHOR INDEX 